Historia: Jurnal Program Studi Pendidikan Sejarah

Vol.3. No. 1 (2018): 33-47

P-ISSN 2301-8305

E- ISSN 2599-0063

\title{
PERANAN PEMERINTAH MENINGKATKAN MANAJEMEN MUTU PENDIDIKAN KOTA BATAM
}

\section{ROLE GOVERNMENT TO INCREASE EDUCATION QUALITY MANAGEMENT IN BATAM'S CITY}

\author{
Nasruji \\ (Prodi Pendidikan Sejarah ,FKIP, Universitas Riau Kepulauan, Indonesia) \\ nasrujisaifulhaq@yahoo.co.id
}

\begin{abstract}
Abstrak
Pendidikan memegang peranan yang sangat penting dalam proses peningkatan kualitas sumber daya manusia dan merupakan suatu proses yang terintegrasi dengan proses peningkatan kualitas pendidikan. Kita menyadari pentingnya proses peningkatan kualitas sumber daya manusia, maka pemerintah telah berupaya mewujudkan amanat tersebut melalui berbagai usaha melalui pengembangan dan perbaikan: (a) manajemen kurikulum; (b) manajemen staf guru dan kependidikan; (c) pengelolaan sarana; (d) manajemen kesiswaan; (e) manajemen sekolah dan masyrakat. Metode penulisan ini menggunakan kualitatif pendekatan analisis naratif deskriptif.
\end{abstract}

Kata Kunci: Manajemen, Mutu, Pendidikan

Abstract

Education holds to play a part that momentous deep qualities increasing process human resource and constituting an integrated process with qualities increasing process education. We realise the importance for quality step-up process human resource, therefore government have gotten effort renders that mandate through various effort pass through development and fixed up: (a) curriculum management; $(b)$ the management of teacher and educational staff; $(c)$ medium managements; $(d$. kesiswaan's management; (e ) schooled managements and masyrakat. This inscriptive method utilizes kualitatif analisis descriptive narrative approaching

Keyword: Management, Educatio, Quality.

\section{PENDAHULUAN}

Pendidikan memegang peranan yang sangat penting dalam proses peningkatan kualitas sumber daya manusia (SDM) dan merupakan suatu proses yang terintegrasi dengan membentuk generasi bangasa yang berdaya saing di era-teknologi, era-indutri 4.0, tentunya melaui peningkatan mutu pendidikan secara berkesinambungan. Kita menyadari bahwa pentingnya proses peningkatan kualitas pendidikan nasional yang merupakan tanggung jawab pemerintah dan stakeholdernya nenjadikan Negara Indonesia maju dari berbagai bidang dalam mewujudkan amanat tersebut melalui berbagai usaha pembangunan pendidikan yang lebih berkualitas melalui pengembangan 
Historia: Jurnal Program Studi Pendidikan Sejarah

Vol.3. No. 1 (2018): 33-47

P-ISSN 2301-8305

E- ISSN 2599-0063

dan perbaikan kurikulum, sistem evaluasi, perbaikan sarana pendidikan, tenaga pengajar yang diberikan pelatihan dan tenaga kependidikan lainnya.

Kualitas pendidikan di Batam dapat meningka dan lebih baikt, maka dianggap perlu terjalinnya kerja sama dari berbagai pihak, baik itu dari pemerintah maupun dari masyarakat sebagai pelaku pengembangan pendidikan dan membangaun generasi bangsa cerdas, dengan harapan daerah akan lebih maju dari berbagai aspek kehidupan. Peran serta masyarakat dalam kemajuan kualitas pendidikan, didasari oleh terlaksananya kooperatif atau terciptanya suatu hubungan timbal balik yang baik antara pemerintah dengan masyarakat, dua belah pihak tersebut pelaku kunci terwujudnya pendidikan bermutu serta pendidikan yang berkemajuan menciptakan manusia berkualitas, menjadikan daerah akan dikelola potensi lingkungan dan sumber daya alam dengan professional.

Sistem pendidikan nasional dimaksud adalah harus mampu menjamin pemerataan kesempatan dan peningkatan mutu pendidikan, peserta didik adalah generasi penerus keberlangsungan, peradaban Bangsa dan Negara Kesatuan Republik Indonesia (NKRI) ada pada mereka yang secara langsung berkontribusi jika mereka telah cerdas, cekatan menciptakan perubahan melalui gagasan kreatif dan inovatif. Saat ini pemerintah sadar pentingnya peningkatan mutu pendidikan melalui berbagai paket program pendidikan sebagai impelementasi penggunaan anggaran pendidikan $20 \%$ dari APBN, utamanya di daerah-daerah tertinggal masih sangat minim dibandingkan dengan kebutuhan masyarakat, anggaran pendidikan 20\% tersebut seringkali hanya program tambal sulam dan tidak berkelanjutan (sustainable).

Batam secara geografi merupakan daerah terdepan, jendela bangsa Republik Indonesia yang secara langsung berhadapan dengan Negara Singapura dan Negara Malaysia, maka pemerintah merasa malu dan menjadi aib atau menampakkan kelemahannya serta kekurangannya jika main-main dalam menangani urusan pendidikan di Batam-Kepulauan Riau (KEPRI). Pada masa pemerintahan Presiden Susilo Bambang Yudhoyono, pendidikan di Batam mengalami kemajuan secara signifikan, saat ini Batam terjadi issue-isu kritis pendidikan yang menjadi renungan dan 
Historia: Jurnal Program Studi Pendidikan Sejarah

Vol.3. No. 1 (2018): 33-47

P-ISSN 2301-8305

E- ISSN 2599-0063

pekerjaan rumah (PR) dari berbagai pihak terutama pemerintah, peraktisi pendidikan, dan budayawan yang dibutuhkan pemikiran-pemikiran jernih arif dalam mencari menyelesaikan dan mencari solusi terbaik untuk mencapai pendidikan yang bermutu.

Gagasan munculnya Education Quality management (EQM) adalah suatu strategi manajemen kurikulum untuk membangun sebuah sekolah dengan kekuatan peran pemerintah dengan masyarakat. Adapun konsep manajemen pendidikan, berarti pemimpin yang kuat atau strong leader mampu menggerakkan semua komponen sekolah, mengaplikasikan semua potensi secara maksimal, sinergis, dangan berkesinambugan dalam lembaga tersebut. Dalam konsep manajerial, kepala sekolah sebagai topleader membangun sistem organisasi untuk mampu meningkatkan mutu sekolah yang sesuai dengan cita-cita Negara yaitu dalam bingkai mencerdaskan kehidupan bangsa yang berdaulat menjaga keutuhan Negara Kesatuan Repubik Indonesia (NKRI) sebagai tujuan utama geberasi bangsa kedepan.

\section{METODOLOGI}

Pendekatan yang digunakan adalah pendekatan kualitatif dengan metode deskriptif. Penelitian deskriptif, bukan hanya bisa mendeskripsikan sesuatu keadaan saja, tetapi bisa juga mendeskripsikan keadaan dalam tahapan perkembangannya baik masa sekarang maupun masa yang telah berlalu . Moleyong (2007:11) bahwa penelitian kualitatif deskriptif yaitu data yang dikumpulkan berupa kata-kata, gambar dan bukan angaka. Berdasarkan pernyataan tersebut bahwa "penelitian kualitatif deskriptif adalah suatu metode penelitian yang tertuju untuk menggambarkan fenomena-fenomena yang ada, yang berlangsung pada saat sekarang ini atau masa yang lampau". Metode kualitatif digunakan untuk mendapatkan data yang mendalam, dan mengandung makna yang sebenarnya. Dalam penelitian kualitatif tidak menekankan pada generalisasi, tetapi lebih menekan pada makna.

Rohiyat (2012:21) bahwa manajemen pendidikan tergantung pada kurikulum yang telah dirumuskan dan disesuaikan dengan filsafat dan cita-cita bangsa yaitu mensesuaikan dengan kebutuhan dan kemampuan peserta didik serta tuntutan kemajuan lingkungan masyrakat. Kurikulum sangat penting yang harus diperhatikan untuk 
Historia: Jurnal Program Studi Pendidikan Sejarah

Vol.3. No. 1 (2018): 33-47

P-ISSN 2301-8305

E- ISSN 2599-0063

menciptakan suatu pola atau sistim pendidikan yang berkualitas tersebut, sistim pendidikan yang dikelola dengan manajemen yang tidak tepat akan menghasilkan kegagalan, dan ini akan menyebabkan kerugian yang sangat besar bagi masyarakat sebagai pelanggan utama lembaga pendidikan.

Sucipto dan Rohiyat (1994:142) menegaskan bahwa kurikulum merupakan peserta dididik disiplin dengan jadwal mata pelajaran yang telah ditetapkan pihak sekolah dan pihak sekolah mmberikan pengalamn belajar kepada siswa dalam upaya menghasilkan lulusan yang baik. Sederhananya bahwa kurikulum adalah segala sesuatu yang diprogramkan oleh sekolah yang akan dipatuhi oleh peserta didik selama di lingkungan sekolah. Oleh karena itu memanajemani kurikulum bisa dipahami sebagai segala usaha dan kerja sama seluruh potensi dalam organisasi pendidikan mulai dari perencanaan, pelaksanaa, sampai penilaian/evaluasi sehingga kurikulum dapat dijalankan dalam rangka mencapai tujuan pendidikan yang telah ditetapkan berdasarkan setandar pendidikan nasional.

William B. Regan, dikutip Arif (2002 :30) bahwa kurikulum meliputi seluruh program dan kehidupan sekolah. Kurikulum tidak hanya meliputi bahan pelajaran, tetapi seluruh kehidupan dan tindakan di ruangan kelas yang berhubungan dengan peserta didik yang merekonstruksi perkembangan dan pengalaman belajar siswa yang terorganisasikan dengan baik, terintegrasi secara berkesinambungan serta konsisten terhadap visi-misi pengelolan pendidikan yang berorientasi pada membangun generasi bangsa kretis, kreatif dan inovatif dalam segala bidang.

Alma (2000:11) bahwa mengajar sebagai seni dan ilmu (teaching is an art and teaching is a science), profesi guru berasal dari masyrakat yang memiliki kompetensi yang diharapkan mampu melakukan ide-ide baru dalam mengembangkan metode pendidikan dengan tujuan peserta didik tidak mudah jenuh mengikuti pembelajaran yang diajarkan, hal ini merupakan usaha menjadi guru yang professional. Berdasarkan Undang-undang Nomor 20 Tahun 2003 tentang sistem pendidikan nasional pasal 1 ayat 5 dan 6 yang dimaksud dengan tenaga kependidikan adalah anggota masyarakat yang mengabdikan diri dan diangkat untuk menunjang penyelenggaraan pendidikan. 
Historia: Jurnal Program Studi Pendidikan Sejarah

Vol.3. No. 1 (2018): 33-47

P-ISSN 2301-8305

E- ISSN 2599-0063

Sedangkan pendidik adalah tenaga kependidikan yang berkualifikasi sebagai guru, dosen, konselor, pamong belajar, widyaiswara, tutor, instruktur, fasilitator dan sebutan lain yang sesuai dengan kekhususannya serta berpartisipasi dalam menyelenggarakan pendidikan.

Santrock (2016: 146) bahwa tiga instrumen umum yang diterapkan dalam perencanaan berpusat pada guru (teacher centered) yaitu: sasaran perilaku, analisis tugas, dan taksonomi pengajaran, dalam hal ini maka peran guru meningkat mutu pendidikan bukan berdasarkan jabatan struktural, akan tetapi capaian pendidikan bermutu jika terjadi sinergitas berbagai pihak, menerima tanggung jawab membimbing, mengajar, dan atau melatih peserta didik. Dalam perkembangannya, tugas dan tanggung jawab tersebut menuntut adanya pengembangan ke arah profesionalisme pendidik dan tenaga kependidikan yang dituangkan dalam Undang-undang Nomor 14 Tahun 2005 tentang guru dan dosen bahwa Peraturan Pemerintah Nomor 19 Tahun 2005 tentang standar nasional pendidikan yang salah satunya menjelaskan tentang standar pendidik dan tenaga kependidikan. Dalam menjalankan tugas dan fungsinya secara profesional guru sebagai tenaga pendidik wajib memiliki kualifikasi akademik, kompetensi, sertifikat pendidik, sehat jasmani dan rohani, serta memiliki kemampuan untuk mewujudkan tujuan pendidikan nasional yaitu mencerdaskan genrasi bangsa. Kompetensi guru sebagaimana dimaksud di atas meliputi kompetensi pedagogik, kompetensi kepribadian, kompetensi sosial dan kompetensi profesional yang diperoleh melalui pendidikan profesi atau keguruan.

Rohiat (2009:27) bahwa tenaga kependidikan yang mengemban tugas dengan dedikasi tinggi, kompleksitas tugas dan tanggung jawab pendidik dan tenaga kependidikan maka dibutuhkan suatu manajemen pengelolaan pendidik dan tenaga kependidikan yang efektif dan efisien. Tentu hal itu bukan tugas yang ringan bagi kepala sekolah selaku pemimpin internal sekolah, karena selain mengusahakan tercapainya tujuan sekolah juga harus tujuan pendidik dan tenaga kependidikan secara holistik proses pembelajaran di ruang kelas. Beberapa tuntutan manajemen PTK yang harus dijalankan meliputi: (1) pemilihan PTK yang cakap, (2) membantu PTK 
Historia: Jurnal Program Studi Pendidikan Sejarah

Vol.3. No. 1 (2018): 33-47

P-ISSN 2301-8305

E- ISSN 2599-0063

menyesuaikan diri dengan tugas-tugas barunya, (3) melakukan penugasan bagi PTK dengan lebih efektif dan (4) menciptakan kesempatan untuk pengembangan PTK secara berkesinambungan.

Hal tersebut diperkuat oleh Endang (2009: 229-251) bahwa implementasi manajemen pendidik dan tenaga kependidikan di sekolah terkait tentang Perencanaan pengembangan dan strategi dalam penyusunan PTK (SDM) yang komprehensif guna memenuhi kebutuhan organisasi di masa depan. Secara spesifik, perencanaan PTK melibatkan kegiatan memperkirakan (forecasting) sumber daya manusia atau PTK, sekaligus merencanakan langkah - langkah pemenuhannya. Kegiatan fungsi ini terdiri dari pengembangan dan penerapan rencana dan program-program untuk menjamin agar jumlah maupun tipe personil yang diperlukan dapat terpenuhi sesuai dengan tempat dimana mereka akan bekerja dengan memenuhi prinsip the right man on the right place on the right job. Karena itu terkait langsung dengan perencanaan organisasi ke depan, maka fungsi ini dipandang sangat penting dalam rangka mencapai tujuan organisasi di masa yang akan datang.

Arcaro (2007:10) manajemn mutu terpadu pada pendidikan adalah suatu usaha untuk mengembangkan pendidikan mutu secara komprehensif, guru yang professional melaksanakan tugasnya akan memberikan kenyamanan dalam proses belajar mengajar. diperkuat oleh Imron (2011:6) bahwa manajemen peserta didik (pupil personel administration) sebagai suatu layanan yang memusatkan perhatian pada pengaturan, pengawasan dan layanan siswa di kelas dan di luar kelas seperti: pengenalan, pendaftaran, layanan individual seperti pengembangan keseluruhan kemampuan, minat, kebutuhan sampai ia matang di sekolah. Manajemen peserta didik dapat pula diartikan sebagai usaha pengaturan terhadap peserta didik mulai dari peserta didik tersebut masuk sekolah sampai dengan mereka lulus sekolah.

Menurut Mitchun (Imron, 2001:98-99) bahwa ada 2 jenis pengelompokkan peserta didik yaitu: (a) ability grouping, yaitu pengelompokkan berdasakan kemampuan peserta didik dalam setting sekolah. Pada pengelompokkan ini peserta didik yang pandai dikumpulkan dengan yang pandai dan yang kurang pandai dikumpulkan dengan 
Historia: Jurnal Program Studi Pendidikan Sejarah

Vol.3. No. 1 (2018): 33-47

P-ISSN 2301-8305

E- ISSN 2599-0063

yang kurang pandai, (b) sub-grouping with in the class, yaitu pengelompokkan peserta didik dalam setting kelas yang selanjutnya dibagi-bagi lagi menjadi beberapa kelompok kecil.

Mulyasa (2009: 49) bahwa dijelaskan secara epistimologis menjadi konsep sarana dan konsep prasarana. Sarana adalah segala bentuk dan jenis peralatan serta perlengkapan yang secara langsung dipergunakan dan menunjang proses pendidikan, khususnya proses belajar mengajar, seperti gedung, ruang kelas, laboratorium, lapangan olah raga, meja kursi serta alat-alat media pembelajaran. Sedangan prasarana pendidikan adalah fasilitas yang tidak secara langsung menunjang jalannya proses pendidikan atau pengajaran, seperti jalan menuju sekolah, halaman sekolah, kebun, taman sekolah dan lain-lainnya, tetapi jika dimanfaatkan secara langsung untuk proses belajar mengajar, seperti taman untuk pengajaran biologi, halaman untuk lapangan olah raga, maka komponen itu merupakan sarana pendidikan.

Sutikno (2012:67) bahwa dalam organisasi terdapat manajemen pengawasan, pengawasan yang efektif diperlukan teknik yang sesuai dengan kondidisi dan situasi yang memungkinkan agar tidak terjadi hal yang tidak diinginkan. Manajemen keuangan adalah fungsi manajemen dalam hal penggunaan dana dan mendapatkan dana yang diperlukan pengawasan secara intensif, bahwa dari mana sumbernya dan kemana dialokasikan, sehingga peran masyrakat terlibat dalam pengelolaan pendidikan sangat dibutuhkan yang berkolaborasi dengan pihak lembaga pendidikan mengoperasikan dana-dana yang dianggarkan pemerintah. Dalam organisasi yang bersifat bisnis pengelolaan keuangan betul-betul merupakan faktor yang sangat menentukan kelangsungan organisasinya yang komitmen terhadap manajemen manajemen keuangan memiliki 3 tahapan penting yaitu: tahap perencanaan (budgeting), tahap pelaksanaan (akunting) dan tahap penilaian (auditing).

Nuraedi dan Rosalin (2009:279) bahwa hubungan sekolah dengan masyarakat dikemukakan oleh Leslie sebagai berikut: "School public relation is a process of communication between theschool and community for purpose of increasing citizen of educational need and practices encouraging intelligent citizen inters and cooperation in 
Historia: Jurnal Program Studi Pendidikan Sejarah

Vol.3. No. 1 (2018): 33-47

P-ISSN 2301-8305

E- ISSN 2599-0063

thework of improving the school”. hubungan sekolah dengan masyarakat adalah suatu proses komunikasi antara sekolah dengan masyarakat untuk meningkatkan pengertian warga masyarakat akan kebutuhan dan pelaksanaan pendidikan yang dilaksanakan sesuai perkembangan teknologi. Informasi komunikasi pendidikan ditengah masyrakat menjadi kebutuhan, karena akan memberikan kemudahan intraksi social pendidikan dan terjalinnya keterbukan antar pihak sekolah dengan stakeholder, perkembangan kemajuan teknologi menjadi hal utama dalam proses pendidikan dengan mengutamakan inforrmasi teknologi komunikasi (ITC) yang memiliki manfaat cukup besar terhadap perkembangan dan kemajuan sekolah, sehingga hubungan antara pihak sekolah dengan masyrakat terjalin harmonisasi. Konsep tersebut didukung oleh Uno (2010:57) bahwa perkembangan teknologi informasi berpungsi untuk meningkatkan kinerja yang fektif, teknologi dapat dapat meningkatkan mutu pendidikan secara signifikan.

\section{HASIL PENELITIAN DAN PEMBAHASAN}

\section{Manajemen Kurikulum}

Manajemen kurikulum pendidikan yang diterapkan di kota Batam adalah komitmennya pemerintah daerah terhadap kebijakan penetapan kurikulum dari pusat yaitu Kementrian Pendidikan dan Kebudayaan (KEMENDIKBUD) atau umumnya kurikulum 2013 pendidikan sentralisasi. Pengorganisasian sistem pendidikan kota Batam masih banyak Coppypaste merupakan regulasi pemerintah daearah kurang kretaifnya dalam mengambil kebijakan untuk bersepekulatif mengambil peran desetralisasi sistem pendidikan nasional dalam menrapkan inovasinya manajemen pendidikan lebih menguntungkan bagi peserta didik. Dalam hal ini kecendrungan pemerintah kota Batam lebih mengedepankan kebijakan pemerintah pusat dari kretaifitas atau singronisasikan kondisi lingkungan sehingga terjadi kemunduran, sebab pada tahun 2011 Batam (KEPRI) pernah sampai peringkat ke 7 (ketujuh) secara nasional, kemenotonannya pemerintah Batam kurang peka dengan lingkungan atau seni menganalisis kurikulum 2013 yang perlu banyak dipertimbangkan, maka nilai-nilai budaya lokal yang berkembang saat tidak sesuai dengan konsep manajemn yaitu "the art 
Historia: Jurnal Program Studi Pendidikan Sejarah

Vol.3. No. 1 (2018): 33-47

P-ISSN 2301-8305

E- ISSN 2599-0063

of coordinating the elemen of factorsnof production towards the achievement of the purposes of an organizations", yaitu terjadinya keberhasilan jika terjadi nilai seni dan mengoordinasi sumber daya organisasi secara utuh untuk tercapainya sebuah tujuan.

Menurut Muhaimin (2009: 35) Manajemen kurikulum pendidikan yang diterapkan pemerintah pusat maka pihak daearah melakukan evaluasi laikkah jika diterapkan? Hal ini tentu dalam pengembangan pendidikan dilakukan melalaui proses kerja sama yang sistematik, sistemik, dan komprehensif yang dilakukan oleh para praktisis pendidikan daerah dengan mengedepankan melaksanakan fungsi-fungsi manajemen seperti perencanaan, pengorganisasian, pengarahan, dan pengendalian dalam mencapai tujuan pendidikan serta mampu pengendalian sumber daya pendidik dan kependidikan untuk mencapai tujuan pendidikan secara efektif dan efisien.

\section{Manajemen Pendidik dan Tenaga Kependidikan (PTK)}

PTK yang terlaksana di kota Batam berjalan dengan baik didasarai oleh kebijakan yang telah ditetapkan oleh sistem pendidikan nasioanal. Tenaga pendidik dan kependidikan dalam proses pendidikan memegang peranan strategis terutama dalam upaya membentuk watak bangsa melalui pengembangan kepribadian dan nilai-nilai yang diinginkan. Manajemen pendidikan merupakan hal penting dilihat dari dimensi pendidikan, peranan pendidik dalam masyarakat Indonesia tetap dominan meskipun teknologi yang dapat dimanfaatkan dalam proses pembelajaran berkembang, tenaga kependidikan mereka bertugas melaksanakan administrasi, pengelolaan, pengembangan, pengawasan dan pelayanan teknis untuk menunjang proses pendidikan pada satuan pendidikan.

Pemerintah Batam berupaya agar proses pendidikan tidak jauh dari ketetapan dan rambu-rambu yang sistem pendidikan nasional, terkait dengan hal tersebut maka pendidikan di kota Batam berjalan baik dan outputnya memuaskan, menjadikan Batam menjadi peringkat terbaik secara nasional, dikarenakan profesionalisme tenaga pendidik dan kependidikan menjadi skala perioritas. Kemajuan di kota Batam semakin dirasakan atas desakan untuk peningkatan mutu pendidikan pada setiap jenis dan jenjang pendidikan yang telah menjadi komitmen pendidikan daerah yang berorientasi pada 
Historia: Jurnal Program Studi Pendidikan Sejarah

Vol.3. No. 1 (2018): 33-47

P-ISSN 2301-8305

E- ISSN 2599-0063

sistem pendidikan nasional, dalam rangaka peningkatan mutu tenaga pendidik dan kependidikan.

Pemerintah Batam yang selalu komitmen terhadap pengelolaan pendidikan secara professional merupakan hal yang utama, sehingga fungsi PTK dianggap sangat urgen menyebabkan perlunya manajemen pendidik dan tenaga kependidikan yang handal dan efektif di setiap lembaga pendidikan. Pemerintah kota Batam berkeyakinan bahwa manajemen pendidik dan tenaga kependidikan menduduki tempat yang strategis guna menjadikan lembaga pendidikan lebih kompetitif dan menguntungkan dalam mempertahankan prestasi yang ada saat ini. Disamping itu, memungkinkan mutu pendidikan kota Batam lebih baik lagi, bilamana pemerintah melakukan kompensasi (gaji, insintif dan lainya) yang membangkitkan motivasi dan profesionalisme guru terhadap kinerjanya akan lebih baik.

Pemerintah kota Batam selalu bersinergi dengan pihak-pihak terkait, karena Batam sebagai kota Industri, maka indutri Batam proaktif terlibat secara implesit mengembangkan pendidikan yang berbudaya dan berkarakter sehingga para alumni sebagai preoritas utama menjadi tenaga pekerja buruh pada perusahaan yang mereka kelola. Adapun upaya-upaya tersebut dianggap sangat positif dalam rangka menjalankan amanat bangsa, mengingat peran pendidik dan tenaga kependidikan yang professional ini menjadi hal penting pemerintah pusat agar responship terhadap perkembangan dan kemajuan pendidikan di kota Batam yang menjadi jendela bangasa berhadapan langsung dengan Negara-negara tetagga, agar meningkatkan kemajuan yang dicapai, tujuan Batam menjadi Bandar Madani, bukan hanya selogan, retorika positif pemerintah Batam bekerja keras mewujudkan cita-cita nasional yantu mampu menjaga mutu pendidikan yang menjadi hal urgens dalam pengembangan kota Batam yang kondusip sebagai pengemban amanah yaitu jadikan Batam menjadi gerbang potensial bangsa berkompetitif dalam pendidikan global.

\section{Manajemen Sarana}

Pemerintah kota Batam tidak boleh lale dalam mengevaluasi sarana pendidikan yang kurang mendukung, saat ini peneliti banyak temuan di lapangan bahwa sarana 
Historia: Jurnal Program Studi Pendidikan Sejarah

Vol.3. No. 1 (2018): 33-47

P-ISSN 2301-8305

E- ISSN 2599-0063

kurang memadai yang harus dibenahi, hal ini tidak dapat dipungkiri bahwa dalam proses pendidikan bahwa kualitas pendidikan tersebut juga di dukung dengan sarana yang menunjang kesetabilan proses pendidikan, monoton tahun 2005 disamakan dengan tahun 2018 maka menjadikan warna kepudaran terhadap mutu pendidikan kota Batam. Standar institusi pendidikan atau sekolah bila terjadi manajemen inovasi pendidikan yang mempengaruhi lingkungan berdasarkan ruang dan waktu, hal ini menunjukkan bahwa peranan sarana sangat penting dalam menunjang kualitas belajar siswa. Adapun yang dimaksud manajemen pengembangan mutu pendididkan yaitu (a) Perencanaan; (b) Pengadaan; (c) Inventarisasi; (d) Penyimpanan; (e) Penataan; (f) Penggunaan; (g) Pemeliharaan; dan (h) Penghapusan. Pengawasan dan evaluasi proses pendidikan yang dikelola oleh sebuah institusi atau lembaga sekolah maka seyogianya dilakukan secara berkesinambungan.

Seperti yang kita ketahui bahwa perpustakaan yang ada disetiap sekolah berbeda-beda. Ada sekolah yang memiliki perpustakaan tetapi memiliki pasokan buku yang sangat terbatas, ada pula sekolahan yang tidak memiliki perpustakaan seperti di kota kecil. Tetapi, jika kita membandingkan perpustakaan yang ada di kota besar, cukup banyak sekolah yang memiliki perpustakaan akan tetapi pasokan buku yang kurang lengkap. Perpustakaan adalah ahal penting yang harus diperhatikan pemerintah, karena perpustakaan adsalah roh sebuah institusi yang dikelolanya, karena siswa mencari referinsi atau ayan belajar adalah berdasarkan pengadaan buku yang memadai.

Pasilitas terhadap proses belajar mengajar adalah hal penting yang secara intens melakukan pengawasan sarana dan prasarana sebagai penujang utama mencapa pendidikan yang bermutu terkait dengan kegiatan pengecekan kelayakan sarana prasarana. Sarana dan prasarana yang sudah tidak layak dipakai atau sudah rusak tersebut hendaknya dilakukan renovasi atau rehabilisasi dari daftar inventarisasi yang dimiliki sekolah. Kegiatan pengawasan sarana dan prasarana yang dilakukan di oleh pemerintah kota Batam dilaksanakan melalui kegiatan pengecekan dan penghapusan agar anggaran dana pemerintah $20 \%$ terealisasi tepat sasaran.

\section{Manajemen Kesiswaan}


Historia: Jurnal Program Studi Pendidikan Sejarah

Vol.3. No. 1 (2018): 33-47

P-ISSN 2301-8305

E- ISSN 2599-0063

Proses manajemen kesiswaan yang direncanakan dan diusahakan secara terorganisir, seluruh peserta didik dapat mengikuti proses belajar mengajar secara efektif dan efisien, mulai dari penerimaan peserta didik hingga keluarnya peserta didik dari suatu sekolah. Nantinya akan di ketahui output dari lembaga tersebut sudah baik atau belum dari manajemen kesiswaan tersebut.

Kewenangan Pemerintah kota Batam dalam jenjalankan tugasnya untuk mengembangkan mutu pendidikan adalah jika manajemen kesiswaan diketahui melalui kepala sekolah secara intesn yang berkaitan dengan latar belakan siswa, perkembangan sisiwa dan melakukan pembinaan sekolah yang berpariatif sifatnya dengan berkelanjutan, pembinaan siswa berada di sekolah, sampai dengan siswa menamatkan pendidikannya. Hal tersebut adalah pekerjaan yang mulia yang harus dilakukan agar proses pembentukan sumber daya manusis (SDM) betul-betul dalam pengawasan intensif sehingga peserta didik merasa terayomi dan proses belajar yang kondusif. Manajemen kesiswaan juga berarti seluruh proses kegiatan yang direncanakan dan diusahakan secara sengaja serta pembinaan terhadap seluruh peserta didik dapat mengikuti proses belajar mengajar secara efektif dan efisien.

\section{Manajemen Hubungan Masyarakat}

Masyarakat adalah sentral pendidikan yang dilibatkan dalam pengelolaan pendididkan, di lingkungan sekolah dibentuk organisasi masyarakat yang dinamakan komite sekolah yang berperan penting sebagai lokomutif marketing pendidikan yang berperan aktif baik di internal sekolah maupun luar sekolah, kegiatan komite sekolah sebagai penyabung komunikasi aktif kepada pihak sekolah maupun pihak masyrakat karena yang bersentuhan langsung sebagai konsultan sekolah dan masyarakat. Ada beberapa prinsip yang perlu dimainkan dan dipertimbangkan dalam pelaksanaan hubungan sekolah dengan masyarakat yaitu: (a) Integrity: hubungan sekolah dengan masyarakat harus terpadu menyampaikan informasi kepada pihak sekolah dan masyarakat disingronisasikan (informasi akademik maupun informasi nonakademik);

(b) Continuity: pelaksanaan hubungan sekolah dengan masyarakat, harus dilakukan secara terus-menerus. Apabila ini terkoordinasi dengan baik, segala program sekolah 
Historia: Jurnal Program Studi Pendidikan Sejarah

Vol.3. No. 1 (2018): 33-47

P-ISSN 2301-8305

E- ISSN 2599-0063

akan berjalan dan berkembang dengan baik; (c) Simplicit: penyederhanaan berbagai informasi yang disajikan kepada pihak sekolah maupun masyarakat; (d) Coverage: informasi hendaknya menyeluruh dan mencakup semua aspek, program ekstra kurikuler, kegiatan kurikuler. (f) Constructive: sekolah memberikan informasi yang konstruktif kepada masyarakat, akan memberikan respon positif tentang sekolah; (g) Adaptability: informasi dilakukan penyesuaian terhadap aktivitas, kebiasaan, budaya (culture) masyarakat.

Peran pemerintah mengeontrol pengelolaan pendidikan di Indonesia mengalami pasang surut, seiring dengan berbagai perubahan situasi politik yang terjadi dalam beberapa dekade waktu terakhir ini. Potensi praktek-praktek "KKN" (korupsi, kolusi dan Nepotisme) susah dihentikan, akibat dari itu semua sangat berimbas pada kebijakan pendidikan di kota Batam. Pola-pola pengaturan proses pendidikan selalu dikontrol secara akuntabel, riabel, dan tras pengelolaan dana pusat sampai sasaran. Pengawasan dana tersebut dialokasikan mulai dari perencanaan, pelaksanaan, sampai pada proses evaluasi dan penilaian hasil pendidikan, saat ini faktanya di lapangan masih banyak permainan yang dilakukan oleh oknum penyelewengan dana, contoh pendidikan wajib belajar 12 tahun yang menjadi tanggung jawab penuh Negara yang menggeratiskan baiaya pendidikan, tetapi pumutan biaya SPP, Pembangunan dan lain masih juga dilakukan oleh pihak pengelolaan pendidikan.

\section{KESIMPULAN DAN SARAN}

Peranan pemerintah meningkatkan manajemen mutu pendidikan kota batam, proses pengelolaan pendidikan agar permasalahan pendidikan dapat diminimalisir, sangat diperlukan peran serta dari masing-masing komponen pendidikan. Terutama guru segabai pelaku dan praktisi pendidikan harus mampu meningkatkan kemampuannya dalam proses manajemen kelas, kemampuan kepala sekolah sebagai manajerial pendidikan. adapun factor-faktor yang menyebabkan turunnya prestasi pendidikan kota Batam yaitu: 
Historia: Jurnal Program Studi Pendidikan Sejarah

Vol.3. No. 1 (2018): 33-47

P-ISSN 2301-8305

E- ISSN 2599-0063

1. Monoton atau kaku untuk menerapkan kurikulum nasional, tidak seni arif kreatif mengembangkannny, padahal selama tidak menyalahi kode etik sistem pendidikan sebagai pihak pengeloala pendidikan dibenarkan melakukan inovasi sistem pendidikan yang terorganisasi yang diselaraskan dengan kebutuhan lingkungan, sehingga manajemen pendidikan akan terselenggara dengan baik dan berkembang sesuai yang diharapkan.

2. Rekrutmen tenaga pendidik dan kependidikan tidak berdasarkan kompetensi, guru mengajar kurang professional, dan tidak berdasarkan kualipikasi pendidikan sehingga banyak guru yang tidak memahami psikologi pendidikan (educational psychology) dan bedagogik, kebijakan ini menyebabkan kurangnya minat belajar peserta didik.

3. Sarana dan perasarana sangan penting dalam proses belajar mengajar, maka pihak terkait akan menjadi cartatan penting dalam meraih pendidikan yang berkualitas dan terintegrasi bukan hanya ucapan, riilnya saat ini di lapangan bahwa banyak sekolah tidak lengkap pasilitas yang dimiliki, ini semua menjadi Pekerjaan Rumah (PR) pemerintah sebagai regulator dalam upaya pembenahan pendidikan di kota Batam dan melakukan pengawasan penggunaan dana $20 \%$ yang dialokasikan kepada pendidikan.

4. Kenyamanan peserta didik adalah tujuan utama karena siswa yang menjadi objek pendidikan dan sekaligus menjadi subjek, pihak sekolah akan menjaga keharmonisasian antarsiswa, dan antara siswa dengan guru, mulai sejak masuk kelas sampai pulang sekolah. Menjadi catatan penting masih banyak siswa di luar lingkungan sekolah pada jam aktif pelajaran, hal ini dari pihak sekolah dan masyarakat memiliki wewenang melakukan saran dan berikan ingatan positif, serta tindakan tegas oleh aparat terkait.

5. Masyarakat sebagai lokomutif marketing pendidikan yang dilibatkan dalam pengelolaan pedagogik, mampu berperan sebagai inisiotor, motivator dan mediator antara pihak sekolah dengan pihak orang tua wali murit yang berperan langsusng sebagai komite sekolah (masyarakat sekolah). Saat ini komite sekolah hanya 
Historia: Jurnal Program Studi Pendidikan Sejarah

Vol.3. No. 1 (2018): 33-47

P-ISSN 2301-8305

E- ISSN 2599-0063

simbolitas saja karena mereka kurang memahami perannya yang seharusnya proaktif dalam kegiatan sekolah, mereka diundang oleh pihak sekolah pada waktuwaktu tertentu jika dibutuhkan, karena dianggap mereka orang-orang luar internal sekolah, sehingga komunikasi tidak terjalin dengan harmonis.

6. Pemerintah kota Batam memiliki peran penting terhadap pengawasan dan evaluasi secara koprehenship dan kontinu terhadap kebijakan kurikulum yang diterapkan oleh pihak sekolah, tenaga pendidik dan kependidikan, sarana dan prasaran kurang memadai yang menjadi isu-isu kritis sistem pendidikan, dan adanya proses belajar mengajar peserta didik kurang menyenangkan yang disebabkan oleh guru yang kurang berkompeten.

\section{REFERENSI}

Arcaro Jerome.J, Pendidikan Berbasis Mutu-Prinsip-Prinsip Perumusan dan Tata Langkah Penerapan,Yogyakarta: Pustaka Pelajar, 2007”

Alma Buchari, Guru Profesional-Menguasai Metode dan Tampilan Mengajar,Bandung: Alfabeta, 2010"

Endang, Herawati dan Nani, Hartini. Manajemen Pendidik dan Kependidikan, Manajemen Pendidikan. Bandung: Alfabeta, 2009.

Makmun Abin Syamsuddin, Psikologi Pendidikan-Perangkat Pngajaran Modol Bandung: PT. Remaja Rosdakarya, 2007"

Moleyong Lexi.J, Metodelogi Penelitian Kualitatif, Bandung: PT. Rosdaka Karya, 2007"

Muhaimin, Manjemen Pendidikan-Aplikasinya dalam Penyusunan Rencana Pengembangan Sekolah, Jakarta: Kencana Prenada Group, 2012

Rohiat. Manajemen Sekolah; Teori Dasar dan Praktek. Bandung: PT. Refika Aditama, 2009"

Sutikno M. Sabri, Manjemen Pendidikan-Langkah Praktis MewujudkanLembga Pendidikan yang Unggul, Mataram: Holistika Lombok, 2012"

Santrock John W., Edication Psychology- Higher Education, New York: McGraw Hill, 2016"

Saifullah, Manjemen Pendidikan Islam, Bandung: CV. Pustaka Setia, 2012”

Uno Hamzah, Teknologi Komunikasi dan Informasi Pembelajaran, Jakarta: PT. Bumi Aksara, 2010" 